were represented on the committee, which included the Radiation Protection Officers of the University and of the United Birmingham Hospitals. The work involving cadavers was done with the permission of the Inspector of Anatomy at the Home Office.

\section{REFERENCES}

Adrian Committee (1960). Radiological Hazards to Patients. Sccond report of the Committee. H.M.S.O., London.

Anderson, J., et al. (1964). Lancet, 21201.
Cameron, J. R., and Sorenson, J. (1963). Science, 142, 230.

Chamberlain M. J., Fremlin, J. H., Peters, D. K., and Philip, Helen (1968a). Radioactive Isotopes in Clinical Medicine and Research. Report of VIII International Symposium. Urban and Schwarzenberg. To be published.

Chamberlain, M. J., Fremlin, J. H., Peters, D. K., and Philip, Helen (1968b). Use of the Cyclotron for Whole Body Neutron Activation Analysis: Theoretical and Practical Considerations. To be published

Kellershohn, C. (1968). Radioactive Isotopes in Clinical Medicine and Research. Report of VIII International Symposium. Urban and Schwarzenberg. To be published.

Simon, G. (1965). Principles of Bone X-ray Diagnosis, 2 nd ed. London.

\title{
Total Body Sodium by Whole Body Neutron Activation in the Living Subject: Further Evidence for Non-exchangeable Sodium Pool
}

\author{
M. J. CHAMBERLAIN,* M.B., M.R.C.P. ; J. H. FREMLIN, † M.A., D.SC., PH.D. \\ D. K. PETERS, $\ddagger$ M.B., M.R.C.P. ; HELEN PHILIP,§ PH.D.
}

Brit. med. F., 1968, 2, 583-585

The existence of a non-exchangeable sodium pool is suggested by the consistently low values for total exchangeable sodium measured by isotope dilution techniques (Edelman et al., 1954 ; Moore et al., 1963) compared with the values for total body sodium derived from chemical analysis of cadavers (Widdowson et al., 1951 ; Forbes and Lewis, 1956 ; Grove and Scott, 1957). The concept is supported by the failure of bone sodium to achieve the same specific activity as plasma sodium after injection of ${ }^{2 \cdot 2} \mathrm{Na}$ (Edelman et al., 1954). Anderson et al. (1964) found only a small difference between exchangeable sodium and whole body sodium determined by whole body neutron activation in two living subjects. These workers suggested that this difference corresponded to the fraction $(<0.5 \%)$ with a long biological half-life in ${ }^{22} \mathrm{Na}$ turnover studies (Miller et al., 1957 ; Richmond, 1958).

We have carried out whole body neutron activation in three normal male subjects and have found a consistent and substantial difference (approximately 17\%) between activatable and exchangeable sodium. Our values for activatable sodium are considerably lower than those for whole body sodium based on chemical analysis of cadavers.

\section{Methods}

These studies were made as part of a programme in which measurements of whole body calcium were also made (Chamberlain et al., 1968c). The conditions of activation of the human subjects, with the use of a cyclotron as neutron source, and the whole body counter have been described previously (Chamberlain et al., 1968a, 1968b).

A 68-kg. polyethylene phantom "standard man" containing $74.9 \mathrm{~g}$. of sodium as sodium chloride dissolved in 57 litres of water was separately activated under comparable conditions except that the irradiation time was increased to 30 minutes to facilitate counting and the irradiation was carried out from one direction only. As in the human studies a wooden coffin $1.5 \mathrm{~cm}$. thick was used to provide moderation of fast neutrons. The activities produced in suitably placed indium foils were taken as a measure of neutron flux.

* Lecturer in Experimental Pathology, University of Birmingham.
+ Professor of Applied Radioactivity, University of Birmingham.

† Professor of Applied Radioactivity, University of Birmingham. Birmingham. Present address: Division of Biophysics, National Institute of Medical Research, London S.W.7.

$\checkmark$ Research Associate in Medical Biochemistry, University of Birmingham.

C
${ }^{24} \mathrm{Na}$ produced from ${ }^{23} \mathrm{Na}$ by neutron capture has a half-life of 15 hours and two gamma emissions of 1.38 and $2.76 \mathrm{MeV}$. Sodium activities in this study are based on measurement of the higher peak in the energy band 2.58-2.92 MeV. Counting for sodium was started approximately three hours after activation, when the short-lived isotopes also produced during activation had decayed away. Counts were repeated three times in the first 30 hours, and the initial ${ }^{24} \mathrm{Na}$ activity was found by extrapolation to time zero. The activity in the energy band counted was shown to have the half-life of ${ }^{24} \mathrm{Na}$. The counting efficiency of the whole body counter for ${ }^{24} \mathrm{Na}$ was measured in the phantom and in each of the three subjects after injection of $2 \mu \mathrm{Ci}$ of ${ }^{24} \mathrm{Na}$ on a separate occasion. The 24 -hour exchangeable sodium was measured a few days later by conventional isotope dilution techniques (Veall and Vetter, 1958) using $20 \mu \mathrm{Ci}$ of ${ }^{24} \mathrm{Na}$.

\section{Results}

The physical characteristics of the three subjects are shown in Table I. It will be seen that J.H.F. and D.K.P. are very similar in weight and build but differ in age, whereas M.J.C. and D.K.P. are very similar in age. The ${ }^{24} \mathrm{Na}$ activities produced in each of the subjects and the phantom are seen in Table II. The corresponding ${ }^{116} \mathrm{In}$ counts are a measure of the neutron flux and so of neutron dose received by each subject.

Total body sodium was calculated from the formula:

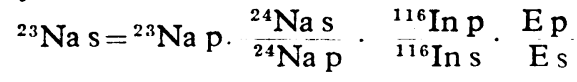

Where: the suffix s denotes the subject.

the suffix $p$ denotes the phantom.

${ }^{23} \mathrm{Na}$ denotes stable sodium.

${ }^{24} \mathrm{Na}$ the radio sodium activity induced.

${ }^{116}$ In the indium activity induced (neutron dose).

$\mathrm{E}$ the efficiency of counting ${ }^{24} \mathrm{Na}$.

Table III gives the values for total body sodium after correction for differences in irradiation and counting efficiency, and contrasts them with the 24-hour exchangeable sodium for each of the three subjects. 
TABLE I.-Physical Characteristics of the Subjects Studied

\begin{tabular}{l|c|c|c}
\hline Subject & Age in Years & Height $(\mathrm{cm})$. & Weight $(\mathrm{kg})$. \\
\hline J.H.F. & 54 & 175 & 76 \\
M.J.C. & 30 & 185 & 85 \\
D.K.P. & 29 & 173 & 75 \\
\hline
\end{tabular}

TABLE II.- Comparison of Na Activity Induced in Each of the Subjects and the Phantom Together with ${ }^{11}$ In Activity (Neutron Dose Received)

\begin{tabular}{l|c|c}
\hline Subject & $\begin{array}{c}\text { 2NNa Activity } \\
\text { (counts/256 sec.) }\end{array}$ & $\begin{array}{c}11 \mathrm{e} \text { In Activity } \\
\text { (counts/60 sec.) }\end{array}$ \\
\hline J.H.F. & 1,870 & 1,206 \\
M.J.C. & 1,677 & 1,113 \\
D.K.P. & 1,570 & 1,099 \\
Phantom & 8,437 & 6,918 \\
\hline
\end{tabular}

TABLE III.-Total Body Sodium by Neutron Activation Compared with 24-Hour Bxchangeable Sodium

\begin{tabular}{|c|c|c|c|c|}
\hline Subject & $\begin{array}{c}\text { Exchangeable } \\
\text { Sodium } \\
\mathrm{mEq} / \mathrm{kg} \text {. (E) }\end{array}$ & $\begin{array}{c}\text { Activatable } \\
\text { Sodium } \\
\mathrm{mBq} / \mathrm{kg} \text {. (A) }\end{array}$ & $\underset{\mathrm{mEq} / \mathrm{kg}}{\mathrm{A}-\mathrm{E}}$ & $\frac{\mathrm{A}-\mathrm{E}}{\mathrm{A}} \%$ \\
\hline $\begin{array}{l}\text { J.H.F. } \\
\text { M.J.C. } \\
\text { D.K.P. }\end{array}$ & $\begin{array}{l}42 \cdot 5 \\
39 \cdot 4 \\
40 \cdot 7 \\
\end{array}$ & $\begin{array}{l}48 \cdot 1 \\
50 \cdot 9 \\
49 \cdot 7 \\
\end{array}$ & $\begin{array}{r}5 \cdot 6 \\
11.5 \\
9 \cdot 2\end{array}$ & $\begin{array}{l}11 \cdot 6 \\
22 \cdot 6 \\
18 \cdot 5\end{array}$ \\
\hline Mean & $40 \cdot 8$ & $49 \cdot 6$ & $8 \cdot 8$ & $17 \cdot 7$ \\
\hline
\end{tabular}

\section{Discussion}

The results of the chemical analysis of all the adult cadavers, in which it is reasonable to assume a normal total body sodium at the time of death, that we are able to find in the literature are summarized in Table IV. These are compared with the results obtained by neutron activation analysis (Anderson et al., 1964, and our own data) and the figures of the International Commission on Radiological Protection (1959) based on unpublished data. The scanty nature of the chemical evidence on total body sodium is seen. Other published results are from cases where the clinical details make it unlikely that the total body sodium was normal at the time of death (Widdowson et al., 1951) or where clinical details are not available (Shohl, 1939). The subject 1951 of Forbes and Lewis (1956) was unconscious for five days before death.

Our values for total body sodium with a mean of 49.6 $\mathrm{mEq} / \mathrm{kg}$. body weight are higher than those of Anderson et al. (1964), but both sets of data obtained from neutron activation give values considerably lower than any of those derived from chemical analysis. Sampling methods were used in all the chemical studies. These are a potential source of error, and the separate estimations necessary for each sample allow the possibility of compounding errors. The results from activation analysis suggest that chemical methods have overestimated total body sodium. We agree with Anderson et al. (1964) that the figure quoted by the International Commission on Radiological Protection (1959) of $65.2 \mathrm{mEq} / \mathrm{kg}$. (105 g. for a $70-\mathrm{kg}$. man) is too high and may give misleading information if used in the assessment of neutron dose after accidental exposure.
The discrepancy between total body sodium determined chemically and exchangeable sodium is evidence for a nonexchangeable sodium pool. Although we have obtained much lower values for total body sodium by neutron activation, a significant and consistent discrepancy between these values and 24-hour exchangeable sodium has been shown in each of our three subjects (Table III). Our values for exchangeable sodium accord well with those of Moore et al. (1963), who give a mean value of $40.5 \mathrm{mEq} / \mathrm{kg}$. for normal males based on 149 subjects aged 16-84 years with a mean body weight of $72.5 \mathrm{~kg}$. The careful experiments of Edelman et al. (1954) suggest that the discrepancy between exchangeable and total body sodium is due to a non-exchangeable sodium pool in bone. These workers took bone biopsies from dogs and a human subject after the administration of ${ }^{22} \mathrm{Na}$, and showed that the specific activity of sodium in bone did not rise significantly above half of that in plasma even after 28 days. Kellershohn (1968), using selective neutron activation of part of a human leg, obtained data suggesting that approximately half of bone sodium is nonexchangeable. Edelman et al. (1954) found no evidence for a non-exchangeable sodium pool in any tissue other than bone. If a skeletal mass of $7 \mathrm{~kg}$. is assumed for a $70-\mathrm{kg}$. man and a sodium concentration in bone of $160 \mathrm{mEq} / \mathrm{kg}$. the skeletal sodium is approximately $1,100 \mathrm{mEq}$, of which $550 \mathrm{mEq}$-that is, approximately $8 \mathrm{mEq} / \mathrm{kg}$. body weight-might be expected to be non-exchangeable. This value corresponds to our finding of a mean activation-exchange difference of $8.8 \mathrm{mEq} / \mathrm{kg}$.

In the light of the evidence for a non-exchangeable sodium pool, it is difficult to understand the failure of Anderson et al. (1964) to demonstrate it. Their condition of irradiation differed from ours. We used predominantly $3 \mathrm{MeV}$ as opposed to $14 \mathrm{MeV}$ neutrons, and therefore obtained greater ${ }^{24} \mathrm{Na}$ activity for approximately the same radiation dose. The use of higher energy neutrons by Anderson et al. would have resulted in some conversion of stable magnesium to ${ }^{24} \mathrm{Na}$, but this would lead to falsely high values for total body sodium. The value for exchangeable sodium in subject S.B.O. of Anderson et al. seems high and may have influenced their conclusions unduly. Their conclusion that there is no significant difference between exchangeable and activatable sodium allows the criticism that neutron activation analysis for the measurement of total body sodium does not provide information that is not available by the use of established isotope dilution techniques. We have shown that this is not so.

It would be of interest to examine the effect of a number of diseases on the size of the non-exchangeable sodium pool. In particular, study of the size of this pool in the acidotic patient with chronic renal failure might provide evidence on the hypothesis that accumulating hydrogen ion is buffered in bone (Goodman et al., 1965).

\section{Summary}

Total body sodium has been measured in three normal adult males by whole-body neutron activation analysis. The values

Table IV.-Total Body Sodium. Comparison of Chemical Analyses on Cadavers Likely to Have Had Normal Total Body Sodium at Time of Death and Results from Neutron Activation of Living Subjects

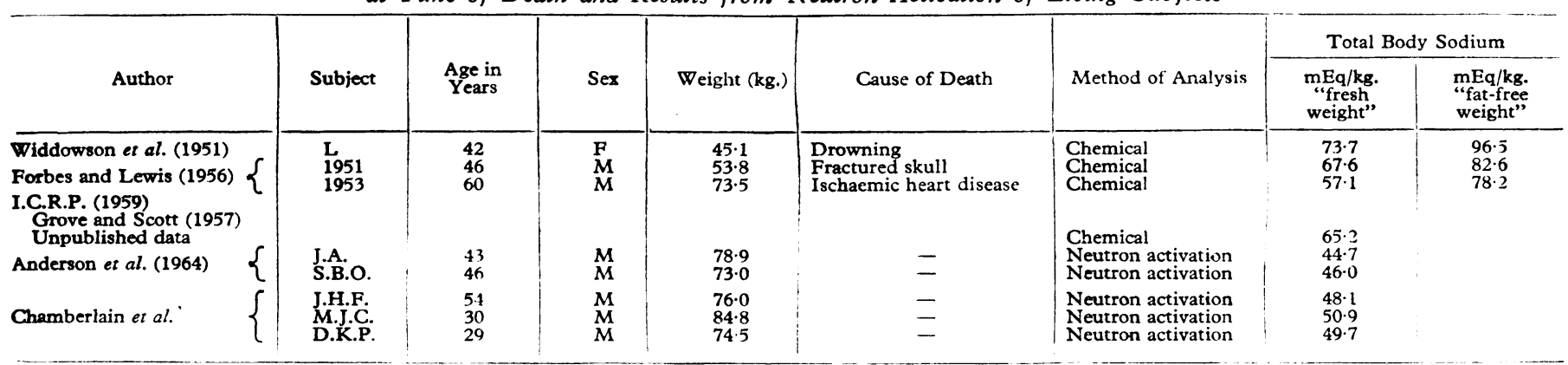


obtained are considerably lower than previously accepted values based on chemical analysis of cadavers. The presence of a significant sodium pool, not detected by isotope dilution techniques, was confirmed.

The techniques described in this paper involving the neutron irradiation of living subjects have been approved by an ethical committee of Birmingham University. Clinicians and physicists were represented on the committee, which included the Radiation Protection Officers of the University and of the United Birmingham Hospitals. The work involving cadavers was done with the permission of the Inspector of Anatomy at the Home Office.

\section{REFERENCES}

Anderson, J., et al. (1964). Lancet, 2, 1201.

Chamberlain, M. J., Fremlin, J. H., Peters, D. K., and Philip, Helen (1968a). Radioactive Isotopes in Clinical Medicine and Research. Report of VIII International Symposium. Urban and Schwarzenberg. To be published.

Chamberlain, M. J., Fremlin, J. H., Peters, D. K., and Philip, Helen (1968b). Use of the Cyclotron for Whole Body Neutron Activation Analysis: Theoretical and Practical Considerations. To be published.
Chamberlain, M. J., Fremlin, J. H., Peters, D. K., and Philip, Helen (1968c). Brit. med. F., 581 .

Edelman, I. S., James, A. H., Baden, H., and Moore, F. D. (1954). 9. clin. Invest., 33, 122.

Forbes, G. B., and Lewis, A. M. (1956). 7. clin. Invest., 35, 596.

Goodman, A. D., Lemann, J., Lennon, E. J., and Relman, A. S. (1965). 7. clin. Invest., 44, 495

Grove, E. L., and Scott, C. W. (1957). Unpublished work quoted by International Commission on Radiological Protection (1959).

International Commission on Radiological Protection (1959). Report of Committee II on Permissible Dose for Internal Radiation. Oxford.

Kellershohn, C. (1968). Radioactive Isotopes in Clinical Medicine and Research. Report of VIII International Symposium. Urban and Schwarzenberg. To be published.

Miller, H., Munro, D. S., and Wilson, G. M. (1957). Lancet, 1, 734.

Moore, F. D., Olesen, K. H., McMurrey, J. D., Parker, H. V., Ball M. R., and Boyden, C. M. (1963). The Body Cell Mass and its Supporting Environment, pp. 76, 77. Philadelphia.

Richmond, C. R. (1958). Los Alamos Scientific Laboratory Report, LA.2207.

Shohl, A. T. (1939). Mineral Metabolism. New York.

Veall, N., and Vetter, H. (1958). Radioisotope Techniques in Clinical Research and Diagnosis. London.

Widdowson, E. M., McCance, R. A., and Spray, C. M. (1951). Clin. Sci., 10, 113 .

\title{
Red Cell Survival Time in Man Measured by ${ }^{50} \mathrm{Cr}$ and Activation Analysis
}

\author{
G. W. K. DONALDSON,* M.B., CH.B., B.SC., M.R.C.P., M.R.C.P.ED. ; P. F. JOHNSON† M.SC. \\ P. TOTHILL, $\ddagger$ B.SC., PH.D., F.INST.P. ; J. RICHMOND, $§$ M.D., F.R.C.P.ED., M.R.C.P.
}

Brit. med. 7., 1968, 2, 585-587

Radioactive isotopes have been used extensively in clinical practice as tracer substances. Chromium-51 as sodium chromate has been used for the measurement of the red cell survival time since Gray and Sterling (1950) demonstrated that hexavalent chromium was a good erythrocyte label. The present work was designed to determine whether non-radioactive sodium chromate might also be used to measure the red cell survival time, the chromium content of the serial blood samples being determined in vitro by neutron activation analysis.

When an element is irradiated with neutrons it may become radioactive, emitting gamma-rays or ionizing particles with energies characteristic of the nuclide produced; moreover, the radioactivity is proportional to the original quantity of the element irradiated. Thus after irradiating a tissue or fluid such as blood, which contains many elements, it is possible to quantitate those elements emitting gamma-rays from measurement of the number and energy of the gamma-rays emitted. The technique has been used to analyse the naturally occurring isotopes present in tissues. It is also possible to add stable isotopes to act as tracers, the amounts in the final samples being determined by neutron activation analysis. This technique has been applied infrequently in clinical practice (Lowman and Krivit, 1963), and we believe this is the first report concerning the use of chromium-50 $\left({ }^{50} \mathrm{Cr}\right)$ or the application of the principle to the determination of the red cell survival time.

\section{Methods}

The method was based on the standard procedures using radioactive sodium chromate (Donohue et al., 1955). From the patient $100-200 \mathrm{ml}$. of blood was taken, anticoagulated with acid-citrate dextrose, and incubated with non-radioactive

\footnotetext{
- Lecturer in Medicine, Royal Infirmary, Edinburgh.

† Research Fellow, Royal Infirmary, Edinburgh.

Principal Physicist, Royal Infirmary, Edinburgh

Senior Lecturer in Medicine and Consultant Physician, Royal Infirmary, Edinburgh.
}

sodium chromate at room temperature. The amount of sodium chromate used was such that the concentration of elemental chromium was less than $10 \mu \mathrm{g} . / \mathrm{ml}$. of red blood cells, a concentration believed not to affect red cell survival (Ebaugh et al., 1953 ; Read et al., 1954 ; Donohue et al., 1955). The red cells were then washed twice in normal saline and resuspended in saline before intravenous infusion. Blood samples were taken subsequently from the patient every few days for up to 30 days for chromium analysis.

Five patients were studied. Their diagnoses are given in the Table. In four the red cell survival time was also determined by means of sodium ${ }^{51}$ chromate, simultaneously with chromium-50 in three of the four. The $T_{t}{ }^{51} \mathrm{Cr}$ was measured by a standard technique ; the radioactivity due to chromium-51 in the serial blood samples was estimated by means of a welltype scintillation counter. (The $\mathrm{T}_{t}{ }^{51} \mathrm{Cr}$ is the time taken for the radioactivity of the blood to reach $50 \%$ of its original value.) In two patients the erythrocyte survival time was measured simultaneously with di-isopropyl phosphorofluoridate with incorporated phosphorus-32 $\left(\mathrm{DF}^{32} \mathrm{P}\right)$. This label was given intravenously in a dose of $10 \mu \mathrm{Ci}$ and the $\beta$ emission of washed haemolysed red cells counted in an M6 liquid $\beta$ counter. $\mathrm{DF}^{32} \mathrm{P}$ does not elute from the red cell and therefore gives a measure of true red cell life-span (Eernisse and van Rood, 1961).

Comparison of Red Blood Cell Isotope Labels

\begin{tabular}{|c|c|c|c|}
\hline Case No. & Diagnosis & Isotope & $T_{1} / 2$ (Days) \\
\hline 1 & Congenital spherocytosis & $\begin{array}{l}{ }^{50} \mathrm{Cr} \\
\mathrm{DF}^{31} \mathrm{Cr} \\
{ }^{31} \mathrm{Cr}\end{array}$ & $\begin{array}{l}12 \\
19 \\
18\end{array}$ \\
\hline 2 & $\begin{array}{l}\text { Autoimmune haemolytic } \\
\text { anaemia }\end{array}$ & ${ }_{{ }^{60} \mathrm{Cr}}^{\mathrm{DF}^{32} \mathrm{P}}$ & $\begin{array}{r}13 \\
8\end{array}$ \\
\hline 3 & $\begin{array}{l}\text { Autoimmune haemolytic } \\
\text { anaemia }\end{array}$ & $\begin{array}{l}{ }^{80} \mathrm{Cr} \\
{ }^{51} \mathrm{Cr}\end{array}$ & $\begin{array}{l}19 \\
20\end{array}$ \\
\hline 4 & $\begin{array}{l}\text { Autoimmune haemolytic } \\
\text { anaemia }\end{array}$ & ${ }^{50} \mathrm{Cr}$ & $\stackrel{10 \cdot 5}{9}$ \\
\hline 5 & Hypertension & ${ }^{50} \mathrm{Cr}$ & $\begin{array}{l}31 \cdot 5 \\
30.5\end{array}$ \\
\hline
\end{tabular}

